\title{
PSAP wt Allele
}

National Cancer Institute

\section{Source}

National Cancer Institute. PSAP wt Allele. NCI Thesaurus. Code C106440.

Human PSAP wild-type allele is located within 10q21-q22 and is approximately $35 \mathrm{~kb}$ in length. This allele, which encodes proactivator polypeptide, plays a role in the positive regulation of lipid hydrolysis. Mutation of the gene is associated with combined saposin deficiency, leukodystrophy metachromatic due to saposin-B deficiency, Gaucher disease, atypical, due to saposin C deficiency, Krabbe disease, atypical, due to saposin A deficiency and Tay-Sachs disease. 